\title{
Predicting growth of Listeria monocytogenes at dynamic conditions during manufacturing, ripening and storage of cheeses - Evaluation and application of models
}

Martinez Rios, Veronica; Gkogka, Elissavet; Dalgaard, Paw

Published in:

Food Microbiology

Link to article, DOI:

10.1016/j.fm.2020.103578

Publication date:

2020

Document Version

Peer reviewed version

Link back to DTU Orbit

Citation (APA):

Martinez Rios, V., Gkogka, E., \& Dalgaard, P. (2020). Predicting growth of Listeria monocytogenes at dynamic conditions during manufacturing, ripening and storage of cheeses - Evaluation and application of models. Food Microbiology, 92, [103578]. https://doi.org/10.1016/j.fm.2020.103578

\section{General rights}

Copyright and moral rights for the publications made accessible in the public portal are retained by the authors and/or other copyright owners and it is a condition of accessing publications that users recognise and abide by the legal requirements associated with these rights.

- Users may download and print one copy of any publication from the public portal for the purpose of private study or research.

- You may not further distribute the material or use it for any profit-making activity or commercial gain

- You may freely distribute the URL identifying the publication in the public portal 


\section{Journal Pre-proof}

Predicting growth of Listeria monocytogenes at dynamic conditions during manufacturing, ripening and storage of cheeses - Evaluation and application of models

Veronica Martinez-Rios, Elissavet Gkogka, Paw Dalgaard

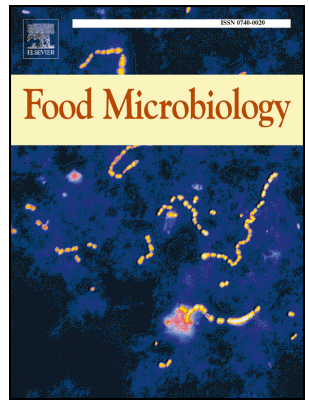

PII: S0740-0020(20)30167-2

DOI: https://doi.org/10.1016/j.fm.2020.103578

Reference: $\quad$ YFMIC 103578

To appear in: Food Microbiology

Received Date: 24 February 2020

Revised Date: 19 May 2020

Accepted Date: 20 June 2020

Please cite this article as: Martinez-Rios, V., Gkogka, E., Dalgaard, P., Predicting growth of Listeria monocytogenes at dynamic conditions during manufacturing, ripening and storage of cheeses - Evaluation and application of models, Food Microbiology (2020), doi: https://doi.org/10.1016/ j.fm.2020.103578.

This is a PDF file of an article that has undergone enhancements after acceptance, such as the addition of a cover page and metadata, and formatting for readability, but it is not yet the definitive version of record. This version will undergo additional copyediting, typesetting and review before it is published in its final form, but we are providing this version to give early visibility of the article. Please note that, during the production process, errors may be discovered which could affect the content, and all legal disclaimers that apply to the journal pertain.

(C) 2020 Published by Elsevier Ltd. 
Predicting growth of Listeria monocytogenes at dynamic conditions during manufacturing, ripening and storage of cheeses - evaluation and application of models

Veronica Martinez-Rios ${ }^{1}$, Elissavet Gkogka ${ }^{2}$, Paw Dalgaard ${ }^{1}$

${ }^{1}$ National Food Institute (DTU Food), Technical University of Denmark, Kgs. Lyngby, Denmark

${ }^{2}$ Arla Innovation Centre, Arla Foods amba, Aarhus N, Denmark

* Corresponding author: Food Microbiology and Hygiene, National Food Institute, Technical University of Denmark, Kemitorvet, Building 202, DK-2800, Kgs. Lyngby, Denmark.

E-mail: veri @food.dtu.dk (V. Martinez-Rios) 


\section{Abstract}

Mathematical models were evaluated to predict growth of L. monocytogenes in mould/smear-ripened cheeses with measured dynamic changes in product characteristics and storage conditions. To generate data for model evaluation three challenge tests were performed with mould-ripened cheeses produced by using milk inoculated with L. monocytogenes. Growth of $L$. monocytogenes and lactic acid bacteria (LAB) in the rind and in the core of cheeses were quantified together with changes in product characteristics over time (temperature, $\mathrm{pH}, \mathrm{NaCl} / \mathrm{a}_{\mathrm{w}}$, lactic- and acetic acid concentrations). The performance of nine available L. monocytogenes growth models was evaluated using growth responses from the present study and from literature together with the determined or reported dynamic product characteristics and storage conditions (46 kinetics). The acceptable simulation zone (ASZ) method was used to assess model performance. A reduced version of the Martinez-Rios et al. (2019) model (https://doi.org/10.3389/fmicb.2019.01510) and the model of Østergaard et al. (2014) (https://doi.org/10.1016/j.ijfoodmicro.2014.07.012) had acceptable performance with a ASZ-score of 71-70\% for L. monocytogenes growth in mould/smearripened cheeses. Models from Coroller et al. (https://doi.org/10.1016/j.ijfoodmicro.2011.09.023) had close to acceptable performance with ASZscores of 67-69\%. The validated models (Martinez-Rios et al., 2019; Østergaard et al., 2014) can be used to facilitate the evaluation of time to critical L. monocytogenes growth for mould/smearripened cheeses including modification of recipes with for example reduced salt/sodium or to support exposure assessment studies for these cheeses.

Keywords: Predictive microbiology, model validation, exposure assessment, food safety, smear cheese, white-mould cheese, blue/white cheese. 


\section{Introduction}

Mould/smear-ripened cheeses have been involved in many listeriosis outbreaks worldwide (Amato et al., 2017; Martinez-Rios and Dalgaard, 2018; McIntyre et al., 2015) and in numerous recalls (FDA, 2018; RASFF, 2019) due to prevalence and high concentrations of L. monocytogenes in the products. Mould/smear-ripened cheeses have a complex microbiota that both evolves throughout production/maturation and affects product characteristics. During fermentation, lactic acid bacteria (LAB e.g. Lactococcus lactis and Leuconostoc species) transforms lactose into lactic acid (ca. 2\%) resulting in lowering of the product $\mathrm{pH}$ to about 5 or below. Thereafter, moulds, yeast or bacteria (e.g. Penicillum camemberti, Penicillum roqueforti, Geotrichum candidum, Debaryomyces hanseii, Brevibacterium linens) can colonize the rind or core of cheeses throughout maturation and contribute to changes in product characteristics including consumption of lacticand/or acetic acids resulting in increased product pH (Leclercq-Perlat et al., 2004; Suzuki-Iwashima et al., 2019).

Improved management of L. monocytogenes in these cheeses is highly relevant and validated predictive models for growth and growth boundary may help to establish process objectives, identify critical control points in HACCP plans (Membré, 2017) or support reformulation of the products. However, documentation is limited on successfully validated $L$. monocytogenes growth models for mould/smear ripened cheeses.

Cardinal parameter models (CPMs) have been developed to predict the growth of $L$. monocytogenes in specific mould/smear-ripened cheeses. Schvartzman et al. (2014) developed a simple model to predict growth of L. monocytogenes in smear- and mould-ripened cheese. This model contained a single term to quantify the effect of $\mathrm{pH}$ and a calibrated optimal growth rate 
parameter $\left(\mu_{o p t}\right)$. The $\mu_{o p t}$-value was calibrated so that model predictions corresponded to the observed growth rate data. Rosshaug et al. (2012) developed a CPM with terms for the effect of temperature, $\mathrm{pH}, \mathrm{NaCl} / \mathrm{a}_{\mathrm{w}}$ and lactic acid concentrations to predict growth of L. monocytogenes in white/blue mould cheese. Schvartzman et al. (2011) used a similar approach to predict growth of $L$. monocytogenes in smear cheese. These studies used very few growth curves $(\leq 4)$ to evaluate the performance of the developed models and product characteristics and their dynamics were not always reported. It has been recommended to use more than 20 kinetics from well-characterized products to evaluate predictive food microbiology growth models (Mejlholm and Dalgaard, 2013; Dalgaard and Mejlholm, 2019) and for instance the evaluation of L. monocytogenes models for seafood and meat relied on hundreds of growth responses (Mejlholm et al. 2010). Therefore, there is a need for further evaluation of L. monocytogenes models to predict growth in mould/smear-ripened cheese. Furthermore, dynamic product characteristics and temperature during manufacturing, ripening and storage of mould/smear-ripened cheeses represented a challenge for prediction of $L$. monocytogenes growth and for the evaluation of growth models. Models for diffusion of lactic acid/lactate and its consumption in smear soft cheese by a specific yeast has been suggested (Aldarf et al., 2006; Riahi et al., 2007). However, models or other tools to predict the dynamic product characteristics of mould/smear-ripened cheeses during manufacturing, ripening and storage are not available. The use of measured dynamic product characteristics as model inputs is another option to predict growth of L. monocytognes in mould/smear-ripened cheeses.

The objectives of the present study were to evaluate mathematical models for their ability to predict growth of L. monocytogenes in mould/smear-ripened cheeses as influences by measured dynamic changes in product characteristics and storage conditions. Firstly, mould-ripened cheese was studied by challenge testing to quantify growth of L. monocytogenes with dynamic changes in storage temperature and product characteristics $\left(\mathrm{LAB}, \mathrm{pH}, \mathrm{NaCl} / \mathrm{a}_{\mathrm{w}}\right.$, lactic- and acetic acid 
concentrations). Secondly, available data for growth of L. monocytogenes in mould/smear-ripened cheese was collected from literature. Finally, the performance of nine available L. monocytogenes growth models was evaluated using a total of 46 kinetics determined experimentally in the present study or obtained from literature together with the corresponding dynamic product characteristics and storage temperature.

\section{Material and methods}

2.1. Bacterial strains and pre-culture conditions

Four dairy related strains of L. monocytogenes were provided by Arla Foods amba and used as a cocktail (SLU92, 612, LM19, 6) for inoculation of challenge tests. Strains were transferred from storage at $-80^{\circ} \mathrm{C}$ to Brain Heart Infusion (BHI) broth (CM1135, Oxoid, Hampshire, UK) and incubated $24 \mathrm{~h}$ at $25^{\circ} \mathrm{C}$. The individual stains were pre-cultured one day at a temperature of $8^{\circ} \mathrm{C}$ in BHI broth with pH 6.7 to simulate milk conditions. Pre-cultures were grown to a relative increase in absorbance $(540 \mathrm{~nm})$ of 0.05 to 0.2 (Novaspec II, Pharmacia Biotech, Allerød, Denmark). A $L$. monocytogenes cocktail of strains (Lm-mix) were produced by mixing equal volumes of the individual pre-cultures. The cell concentration of $L m$-mix was determined by direct phase-contrast microscopy at 1000x magnification considering that one cell per field of view corresponded to a concentration of around $10^{6} \mathrm{cfu} / \mathrm{ml}$ (Adams et al., 2016).

2.2. L. monocytogenes growth and measured dynamic product characteristics for mould-ripened cheese 
Three challenge tests were performed to quantify growth of L. monocytogenes in three differently formulated white mould-ripened cheeses (see section 2.2.1). Growth in the rind and in the core of the cheeses were quantified separately and a total of 18 growth/no-growth responses were generated together with quantification of changes in storage conditions (temperature) and product characteristics ( $\mathrm{pH}, \mathrm{NaCl} / \mathrm{a}_{\mathrm{w}}$, lactic- and acetic acids) (see section 2.2.2 and Figures 1,2 and 3).

\subsubsection{Production of white mould-ripened cheeses}

Pasteurized milk with $3.5 \%$ fat was purchased from a local supermarket and used for cheese making in the laboratory. The milk was heated to $30-32^{\circ} \mathrm{C}, 0.4 \mathrm{ml} / \mathrm{L}$ of a $50 \% \mathrm{CaCl}_{2} \mathrm{w} / \mathrm{v}$ solution was added and then the milk was inoculated with different commercial LAB starter culture along with mould and/or yeast as ripening microbiota in order to simulate production of different white mould cheeses. For the first challenge test, milk $(25.5 \mathrm{~L})$ was inoculated with a freeze-dried probiotic strain $(0.01 \mathrm{~g} / \mathrm{L}$ of Lactobacillus acidophilus, LA-5, Chr. Hansen A/S, Hørsholm, Denmark), a freeze dried DL-culture $(0.13 \mathrm{~g} / \mathrm{L}$ of L. lactis subsp. cremoris, L. lactis subsp. lactis, Leuconostoc spp. and L. lactis subsp. lactis biovar diacetylactis, FLORA ${ }^{\mathrm{TM}}$ C501, Chr. Hansen $\mathrm{A} / \mathrm{S})$ and a ripening culture $(4 \mathrm{mg} / \mathrm{L}$ of $P$. camemberti, PC HP $6 \mathrm{LYO}$ and $2 \mathrm{mg} / \mathrm{L}$ of $G$. candidum, GEO 17, DuPont ${ }^{\mathrm{TM}}$ Danisco®, Brabrand, Denmark). For the second challenge test, milk (24.5 L) was inoculated with a freeze dried DL-culture $\left(0.13 \mathrm{~g} / \mathrm{L}\right.$ of FLORA ${ }^{\mathrm{TM}} \mathrm{C} 503, \mathrm{Chr}$. Hansen A/S $)$ and a ripening culture $\left(2 \mathrm{mg} / \mathrm{L}\right.$ of $G$. candidum, GEO 17, DuPont ${ }^{\mathrm{TM}}$ Danisco $\left.{ }^{\circledR}\right)$. For the third challenge test, milk (53 L) was inoculated with a freeze dried DL-culture $(0.02 \mathrm{~g} / \mathrm{L}$ of L. lactis subsp. cremoris, L. lactis subsp. lactis, Leuconostoc spp. and L. lactis subsp. lactis biovar diacetylactis, CHN-11, Chr. Hansen A/S, Hørsholm, Denmark) and a ripening culture (6 mg/L of P. camemberti, SWING FD PCA-3 and 5 mg/L of G. candidum, SWING GEO CD-1, Chr. Hansen A/S). 30 
minutes after the addition of cultures and in order to ensure an even distribution in the final product, milk was inoculated with $0.1 \%(\mathrm{v} / \mathrm{w})$ of $\mathrm{Lm}$-mix appropriately diluted in chilled saline water $(0.85 \%$ $\mathrm{NaCl}$ ) to obtain an initial concentration of $1 \log \mathrm{cfu} / \mathrm{ml}$ of milk. Subsequently, $0.2 \mathrm{ml} / \mathrm{L}$ of rennet CHY-MAX ${ }^{\circledR}$ Plus (Chymosin, Chr. Hansen) for challenge test one and two or CHY-MAX ${ }^{\circledR}$ Special (Chymosin, Chr. Hansen A/S) for challenge test three was added to the milk. 60 minutes after rennet addition, the coagulum was cut into cubes with $1 \mathrm{~cm}$ edge and gently stirred for 5 sec. every $5 \mathrm{~min}$ during $30 \mathrm{~min}$. The curd was transferred into round moulds $(11.4 \mathrm{~cm}$ diameter and $8.5 \mathrm{~cm}$ height) and let to stand for draining of the whey at $20^{\circ} \mathrm{C}$ during $20-22 \mathrm{~h}$. After six hours within the draining process the cheese moulds were flipped over. Cheeses were then removed from the moulds and cut vertically into halves. For the first and second challenge tests, cheeses were immersed 30 min. in brine (18-20\% salt) at a temperature of $18^{\circ} \mathrm{C}$. For the third challenge test, cheeses were drysalted on the surface. After brining/salting by hand, cheeses were transferred to open maturation boxes placed in an incubator (TC $175 \mathrm{~S}$, Lovibond ${ }^{\circledR}$, Amesbury, UK) and dried during $5 \mathrm{~h}$ at $18^{\circ} \mathrm{C}$. Thereafter, maturation boxes were closed and cheeses were incubated at $10^{\circ} \mathrm{C}$ for 5 days. Temperature was increased to $12^{\circ} \mathrm{C}$ one week after the beginning of the fermentation in order to reach the optimum ripening temperature (Leclercq-Perlat et al., 2015). Cheeses were stored up to 30 days at a relative humidity of $90-95 \%$ as measured by data loggers (Tinytag view, Gemini Data Loggers Ltd, Chichester, UK). 60 cheeses $(60 \pm 10 \mathrm{~g})$ were produced for each of the challenge tests one and two, whereas 120 cheeses $(60 \pm 10 \mathrm{~g})$ were produced for challenge test three.

\subsubsection{Product characteristics and microbiological analysis}

For each of the three batches of white-mould cheese, product characteristics were determined separately and in triplicate for the rind and for the core, respectively. Product characteristics were determined during storageat every time of microbiological sampling. $\mathrm{pH}$ was 
measured with a PHC10801 puncture combination probe (Hach, Brønshøj, Denmark) placed directly into the rind or core of each analysed cheese. $\mathrm{NaCl}$ was quantified by automated potentiometric titration (785 DMP Titrino, Metrohm, Hesisau, Switzerland) and $\mathrm{a}_{\mathrm{w}}$ was measured by a water activity meter (Aqua Lab model CX-2, Decagon devices Inc., Pullman, US). The concentration of organic acids were determined by HPLC using external standard of lactic-, aceticand citric acids for identification and quantification (Dalgaard and Jørgensen, 2000; Østergaard et al., 2014). To determine water phase concentrations of salt and organic acids the dry matter content was determined by oven drying at $105^{\circ} \mathrm{C}$ for $24 \pm 2 \mathrm{~h}$. Storage temperature was regularly recorded by data loggers placed inside the cheeses during maturation and storage (TinytagPlus, Gemini Data Loggers Ltd, Chichester, UK).

At each time of sampling in each challenge test, three cheeses $(60 \pm 10 \mathrm{~g})$ were analysed. Cheese rind samples were obtained from the $5 \mathrm{~mm}$ exterior layer of each cheese and core samples were taken from the centre of each cheese. $10 \mathrm{~g}$ of cheese rind or cheese core were independently diluted 10 -fold with chilled physiological saline water $(0.85 \% \mathrm{NaCl}$ and $0.10 \%$ Bacto-peptone, BD Difco $^{\mathrm{TM}}$, Wokingham, UK), homogenized for $30 \mathrm{~s}$ at normal speed in a Stomacher 400 (Seward Medical, London, UK) and then 10-fold serially dilutions were performed with chilled physiological saline water. Lactic acid bacteria (LAB) were enumerated by double layer pour plating in nitrite actidionine polymyxin (NAP) agar with $\mathrm{pH} 6.2$ and incubated at $25^{\circ} \mathrm{C}$ for $72 \mathrm{~h}$ (Davidson and Cronin, 1973). Viable counts of L. monocytogenes were determined by surface plating on PALCAM agar base (CM0877, Oxoid, Hampshire, UK) with PALCAM selective supplement (SR0150, Oxoid, Hampshire, UK) and incubation at $37^{\circ} \mathrm{C}$ for $48 \mathrm{~h}$.

2.3. Collection of data from the scientific literature 
The present study attempted to collect all accessible data for growth of L. monocytogenes in mould/smear-ripened cheeses with reported dynamic product characteristics as well as with dynamic or constant storage temperature. Schvartzman et al. (2011) inoculated pasteurized and raw milk used to produce a smear-ripened cheese with a single strain of the pathogen (C5, serotype $4 \mathrm{~b}$, isolated from cow faeces). The authors observed growth of L. monocytogenes during ripening of the smear cheese produced with raw milk and reported changes in $\mathrm{pH}, \mathrm{a}_{\mathrm{w}}$ and L-lactic acid concentrations in the rind and core. Rosshaug et al. (2012) inoculated a 13 days old blue/white mould cheese with the type strain of L. monocytogenes (ATCC 19115) and reported changes in storage temperature, $\mathrm{pH}$, salt and lactic acid concentrations in the product over time. Schvartzman et al. (2014) inoculated the surface of a 25 days old mould cheese and 30 days old smear-ripened cheeses with a two strain cocktail of $L$. monocytogenes $(6179$, serotype $1 / 2 \mathrm{a}$, isolated from cheese and $\mathrm{C} 5$, serotype $4 \mathrm{~b}$, isolated from cow faeces). Along with growth, changes in $\mathrm{pH}$ and $\mathrm{a}_{\mathrm{w}}$ of the product were measured over time. Dalzini et al. (2017) inoculated three different batches of Gorgonzola cheese slices with the L. monocytogenes type strain (ATCC 19115) or with a cheese isolate ( $\mathrm{Lm} 273250)$. The authors reported average values for $\mathrm{pH}$ and $\mathrm{a}_{\mathrm{w}}$ for three different batches of cheese that were analysed at different days (1, 14, 21, 49 and 100 days) of the challenge test at a constant storage temperature of $8^{\circ} \mathrm{C}$. The PlotDigitizer v. 2.6.8 software (https://sourceforge.net/projects/plotdigitizer/files/) was used to extract data from graphs for $L$. monocytogenes growth in cheese, product characteristics and storage conditions for cheeses and results are shown in Supplementary material Table 1 and 2.

\subsection{Predictive food microbiology models}

The performance of nine predictive models for growth of L. monocytogenes in cheese was evaluated. These cardinal parameter models (CPM) were developed and evaluated to predict growth 
of L. monocytogenes in cheeses (Table 1; Supplementary material). The number of environmental factors included in the studied models varied from one to five. The least complex model took into account exclusively the effect of $\mathrm{pH}$, although it is well stablished that extensive models are necessary to accurately predict growth of L. monocytogenes in foods (Mejlholm et al., 2010). This simple model was included to determine the difference in performance when compared to more extensive models including the combined effect of organic acids, other product characteristics and interaction between environmental factors. A detailed description of the nine studied models including specific equations, parameter values used for simulations, assumptions and interaction terms has been provided as Supplementary material.

\subsection{Simulation and evaluation of models}

Growth simulation with the different models and based on product characteristics and storage conditions for the different studies were performed using Microsoft Excel 2016 (Microsoft Corp. Redmond, WA, USA). The Euler-method for numerical integration (Press et al., 2007) was applied with a step-length of $0.5 \mathrm{~h}$ to predict growth under dynamic storage temperature and product characteristics and by using the differential form of the primary logistic model (Rosso et al., 1996) with delay $\left(d N / d t=0\right.$ for $t<t_{\text {lag }}$ and $d N / d t=N \cdot \mu_{\max } \cdot\left(1-\left(N / N_{\max }\right)\right)$ for $\left.t \geq t_{\text {lag }}\right)$. Parameter values were initial cell concentration $(N, \mathrm{cfu} / \mathrm{g})$, maximum specific growth rate $\left(\mu_{\max }, \mathrm{h}^{-1}\right)$, maximum population density $\left(N_{\max }, \mathrm{cfu} / \mathrm{g}\right)$, storage time $(t, \mathrm{~h})$ and lag time $\left(t_{\text {lag }}, \mathrm{h}\right)$. Growth simulations were performed using the initial cell concentrations observed experimentally (see section 2.2.2) or values reported in the literature (see section 2.3). The maximum cell concentration was assumed to be a constant value $(7.4 \mathrm{log} \mathrm{cfu} / \mathrm{g})$ for all the simulations performed. It was calculated as an average value $(\mathrm{n}=19)$ from maximum populations of $L$. monocytogenes observed in mould-ripened cheeses growth kinetics at different temperatures (Kapetanakou et al., 2017; Lobacz et al., 2013). 
The acceptable simulation zone (ASZ) approach was used to compare predictions from the different models (see section 2.4) with experimentally determined growth (see section 2.2) and with observations extracted from the literature (see section 2.3). The acceptable interval was defined as $\pm 0.5 \mathrm{log} \mathrm{cfu} / \mathrm{g}$ from the simulated growth of L. monocytogenes as suggested by Oscar (2005) and with $0.5 \log \mathrm{cfu} / \mathrm{g}$ corresponding to the precision of microbiological testing in food (FAO/WHO, 2009). Fail-safe and fail-dangerous predictions had, respectively, differences between observed and predicted value below $-0.5 \log \mathrm{cfu} / \mathrm{g}$ and above $+0.5 \log \mathrm{cfu} / \mathrm{g}$. When at least $70 \%$ of the predicted cell concentrations $(\log \mathrm{cfu} / \mathrm{g})$ were within the ASZ, the simulation was considered acceptable (Oscar, 2005; Velugoti et al., 2011).

\section{Results}

3.1. L. monocytogenes growth and dynamic product characteristics for mould-ripened cheese

In challenge test one and two, L. monocytogenes grew during the first $22 \mathrm{~h}$ of cheese making. Concentrations increased from $1.0 \pm 0.2$ to $2.7 \pm 0.3 \log \mathrm{cfu} / \mathrm{g}$ while the temperature decreased from $32^{\circ} \mathrm{C}$ to $16.5^{\circ} \mathrm{C}$, $\mathrm{pH}$ decreased from $6.5 \pm 0.0$ to $4.8 \pm 0.1$ and the concentration of lactic- and acetic acids in the water phase increased from non-detectable to $1.7 \pm 0.2 \%$ and $0.2 \pm 0.0 \%$, respectively. At the same time, the added LAB grew to their maximum cell concentration $(8.6 \pm 0.3 \log \mathrm{cfu} / \mathrm{g})$ and caused the observed increase in lactic- and acetic acid concentrations with the corresponding decrease of $\mathrm{pH}$ (Fig. 1 and 2). From $22 \mathrm{~h}$ until four days of storage, the concentration of L. monocytogenes remained constant or decreased slightly in the core but increased in the rind of the mould-ripened cheese (Fig. 1 and 2). After four days of storage in challenge tests one and two, the concentration of $\mathrm{NaCl}(\%)$ in the water phase and $\mathrm{a}_{\mathrm{w}}$ showed little 
variability with values of $3.7 \pm 0.2(\%)$ and $0.979 \pm 0.001$, respectively as found in several previous studies (Guinee and Fox, 2017; Leclercq-Perlat et al., 2013).

In challenge test one, growth of L. monocytogenes was observed in the white-mould cheese rind from day four until day 15 and during this period where $\mathrm{pH}$ increased from $4.7 \pm 0.0$ to $5.8 \pm 0.0$, the lactic- and the acetic acid concentrations in the water phase decreased from $1.8 \pm 0.1 \%$ to $0.2 \pm 0.0 \%$ and from $0.1 \pm 0.0 \%$ to non-detectable, respectively (Fig. 1a and 1c). In the rind, $L$. monocytogenes reached a concentration of $6.8 \pm 0.2 \mathrm{log} \mathrm{cfu} / \mathrm{g}$ after 28 days of storage when $\mathrm{pH}$ was $7.3 \pm 0.0$ (Fig. 1a). In the core, $\mathrm{pH}$-values were lower than in the rind after 15 and 28 days of storage $(5.0 \pm 0.1$ and $6.3 \pm 0.3)$ and a final cell concentration of $4.2 \pm 0.0 \log$ L. monocytogenes/g in the core was observed at day 28 (Fig.1b and 1d).

In challenge test two, the concentration of $L$. monocytogenes decreased from $3.0 \pm 0.1 \mathrm{log}$ cfu/g on day four to $1.4 \pm 0.4 \log \mathrm{cfu} / \mathrm{g}$ on day 15 of storage (Fig. 2a). Growth was then observed in the rind of the white-mould cheese at day 21 following an increase of $\mathrm{pH}$ from $5.3 \pm 0.1$ to $6.8 \pm 0.2$ (Fig. 2c). L. monocytogenes reached a concentration in the rind of $4.0 \pm 0.9 \log \mathrm{cfu} / \mathrm{g}$ on day 28 when $\mathrm{pH}$ was $6.9 \pm 0.1$ (Fig. 2a and 2c). For the core, L. monocytogenes reached a concentration of $2.5 \pm 0.9$ $\log \mathrm{cfu} / \mathrm{g}$ with a $\mathrm{pH}$ of $5.5 \pm 0.3$ and a lactic acid concentration of $0.5 \pm 0.0 \%$ after 28 days of storage (Fig. $2 b$ and $2 d$ ).

For challenge test three L. monocytogenes grew during the first $25 \mathrm{~h}$ of cheese making with concentrations increasing from $2.2 \pm 0.0$ to $3.9 \pm 0.2 \mathrm{log} \mathrm{cfu} / \mathrm{g}$. The temperature decreased from $33^{\circ} \mathrm{C}$ to $16^{\circ} \mathrm{C}, \mathrm{pH}$ decreased from $6.5 \pm 0.0$ to $4.7 \pm 0.1$ and the concentration of lactic- and acetic acids in the water phase increased from non-detectable to $1.6 \pm 0.5 \%$ and $0.2 \pm 0.0 \%$, respectively (Fig. 3). From $25 \mathrm{~h}$ and until the end of storage, inactivation of L. monocytogenes was observed both in the 
rind and in the core of the studied cheese (Fig. 3a and 3b). This might be due to a low water activity of $\sim 0.94$ on day two that decreased to $\sim 0.88$ on day seven combined with a low pH (Fig. 3e and 3f).

3.2. Evaluation of L. monocytogenes growth models for mould/smear-ripened cheese under dynamic product characteristics and/or storage temperature

For challenge test one on day 15, a reduced version of the Martinez-Rios et al. (2019) model (Eq. (24)) predicted L. monocytogenes concentrations of $4.6 \mathrm{log} \mathrm{cfu} / \mathrm{g}$ in the rind and $2.8 \mathrm{log} \mathrm{cfu} / \mathrm{g}$ in the core when the corresponding observed values were $4.0 \pm 0.4$ and $2.6 \pm 0.4 \log \mathrm{cfu} / \mathrm{g}$, respectively. On day 28 , values of $7.4 \mathrm{log} \mathrm{cfu} / \mathrm{g}$ in the rind and $7.3 \mathrm{log} \mathrm{cfu} / \mathrm{g}$ in the core were predicted for L. monocytogenes while the observed values in the rind and the core were $6.8 \pm 0.2$ and

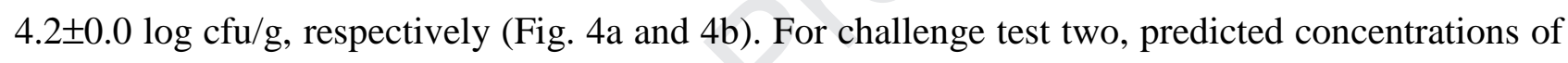
L. monocytogenes in the rind and core after 15 days were $3.1 \log \mathrm{cfu} / \mathrm{g}$ in the rind and $2.9 \log \mathrm{cfu} / \mathrm{g}$ in the core whereas the observed values were lower within both the rind $(1.4 \pm 0.4 \log \mathrm{cfu} / \mathrm{g})$ and core $(2.1 \pm 0.2 \log \mathrm{cfu} / \mathrm{g})$. On day 28 , the model predicted $7.4 \mathrm{log} \mathrm{cfu} / \mathrm{g}$ in the rind and $3.4 \log \mathrm{cfu} / \mathrm{g}$ in the core while the observed values were $4.9 \pm 0.9$ and $2.5 \pm 0.9 \log \mathrm{cfu} / \mathrm{g}$, respectively (Fig. $4 \mathrm{c}$ and 4d). Eq. (24) overestimated growth of L. monocytogenes in the core for challenge test one (Fig 4c). For challenge tests two overestimated growth occurred both in the rind and core of cheese at day 28. However, predictions at day 15 were acceptable for cheese as for rind and the core of challenge test two cheese (Fig. 4b, 4d). For the 12 kinetics (4 growth curves in triplicate) from challenge test one and two with white mould cheese, $69 \%$ of the observed cell concentrations were within the ASZ for predictions with eq. (24) at dynamic storage temperatures and product characteristics (Fig. 4; Table 2). When predictions were performed without taking into account the measured concentrations of lactic- and acetic acids in the water phase or by excluding the effect of interaction between the environmental factors (Le Marc et al., 2002) then the obtained average ASZ-values were much 
lower (57\% and 39\%) as predicted growth rates were markedly faster than observed (Table 3). For challenge test three at $25 \mathrm{~h}$, eq. (24) predicted L. monocytogenes concentrations of $4.1 \mathrm{log} \mathrm{cfu} / \mathrm{g}$ in the rind and in the core when the observed values were $3.8 \pm 0.3$ and $3.9 \pm 0.1 \log \mathrm{cfu} / \mathrm{g}$, respectively. From $25 \mathrm{~h}$ and until the end of challenge test three the model predicted no-growth of $L$. monocytogenes in rind and core based on the measured product characteristics storage temperature, despite the observed inactivation and therefore challenge test three was excluded when calculating the ASZ. Eq. (24) was able to acceptably predict growth of L. monocytogenes in white/blue mould cheese and smear cheese (Rosshaugh et al., 2012; Schvartzman et al., 2011) with, respectively, $100 \%$ and $88 \%$ of the predictions within the ASZ (Table 2). $72 \%$ of the observations from a total of 18 kinetics in well characterized mould/smear-ripened cheese, were within the ASZ (Table 2). In contrast, eq. (24) was unable to accurately predict growth of L. monocytogenes as observed by Dalzini et al. (2017) and Schvartzman et al. (2014) (Table 2 and Fig. 5). Dalzini et al. (2017) and Schvartzman et al. (2014) did not quantify the concentrations of lactic or acetic acids and reported exclusively an average storage temperature, $\mathrm{pH}$ and $\mathrm{a}_{\mathrm{w}}$ for the different batches of cheese. Furthermore, the used of different starter cultures might have had an effect on the growth of $L$. monocytogenes beyond the measured product characteristics. Specifically, Gorgonzola cheese studied by Dalzini et al. (2017) was produced using Streptococcus thermophilus and Lactobacillus delbrueckii subsp. bulgaricus as starter cultures rather than the DL-cultures (L. lactis subsp. cremoris, L. lactis subsp. lactis, Leuconostoc spp. and L. lactis subsp. lactis biovar diacetylactis) used in the present study and both by Rosshaugh et al. (2012) and Schvartzman et al. (2011). Schvartzman et al., (2014) did not provide information about starter cultures used in the production of smear- and mould-ripened cheeses used in their study.

Eq. (24) acceptably predicted growth of L. monocytogenes in one of the smear-ripened cheeses and one of the mould-ripened cheese based on product characteristics reported by 
Schvartman et al. (2014) (Fig. 5b and 5c). However, the model failed to predict the growth observed in a different batch of smear-ripened cheese (Fig. 5a). Similarly, eq. (24) was able to predict growth of L. monocytogenes ATCC 19115 and Lm273250 in Gorgonzola cheese based on the reported product characteristics for batch $\mathrm{C}$ (Fig. $5 \mathrm{f}$ and $5 \mathrm{i}$ ) but the model overestimated growth of both strains in batch A and B of Gorgonzola cheese (Fig. 5d, 5e, 5g, 5h).

Based on the performed model evaluation, the range of applicability for eq. (24) included storage temperatures from $0^{\circ} \mathrm{C}$ to $33^{\circ} \mathrm{C}, \mathrm{pH}$ between 4.5 and 7.3 , water phase salt from $0 \%$ to $5.0 \%$, water phase lactic acid from 0 to $2.0 \%(222 \mathrm{mM})$ and water phase acetic acid between 0 and $0.2 \%$ (36 mM). Variable model performance was observed, particularly, for insufficiently characterized cheeses (Fig. 5; Table 2) and further evaluation of models with well characterized mould/smearripened cheeses, including gorgonzola, is needed.

For these 18 kinetics the performance of the Augustin model in Coroller et al. (2012) and of the Østergaard et al. (2014) models were close to acceptable with, respectively, 69\% and $67 \%$ of predictions within the ASZ (Table 2). With 26-63\% of the predictions within the ASZ the remaining evaluated models failed to acceptably predict growth of L. monocytogenes in mould/smear-ripened cheeses with dynamic product characteristics and storage conditions (Table 2).

None of the evaluated models were able to accurately predict the growth observed by Dalzini et al. (2017) for Gorgonzola cheese slices and by Schvartzman et al. (2014) for smear-ripened cheese based on the reported average values of product characteristics and storage temperature (Table 2). This highlights the importance of knowing changes in relevant product characteristics to predict L. monocytogenes in mould/smear-ripened cheeses. 


\section{Discussion}

It is evident from the present and several previous studies that mould/smear-ripened cheeses support growth of L. monocytogenes due to activity of the mould/smear microbiota resulting in organic acid consumption and increasing product $\mathrm{pH}$ during ripening and storage (Fig. 4; Back et al., 1993; D'Amico et al., 2008; Leclercq-Perlat et al., 2006; Liu et al., 2007; Picque et al., 2006; Ryser and Marth, 1987). Depending on storage temperature and time of potential contamination with L. monocytogenes critical concentrations of the pathogen above $100 \mathrm{cfu} / \mathrm{g}$ may be attained (ANZ, 2018; CA, 2011; EC, 2005) and focus on evaluation and management of this hazard is important.

A single model was identified to predict growth of L. monocytogenes in different mould/smear-ripened cheeses from measured changes in storage temperature and product characteristics (Eq. (24); Fig. 4; Table 2). This reduced version of the Martinez-Rios et al. (2019) model allowed L. monocytogenes growth in both rind and core of chesses to be predicted with near to acceptable accuracy. This is the first study where growth of L. monocytogenes in different mould/smear-ripened cheeses have been acceptably predicted for all accessible data $(n=18)$ from fully characterized cheeses by a single model, an important aspect For practical application of predictive microbiology with this group of cheeses. However, further evaluation of the model with additional dynamic data from well characterized cheese is desirable. The growth and growth boundary model of Martinez-Rios et al. (2019) included the effect of ten environmental factors and eq. (24) might easily be expanded to include the effect of for example $\mathrm{CO}_{2}$ to predict growth of $L$. monocytogenes in modified atmosphere packed cheeses and with the effect of citric acid that might be relevant for other types of cheeses (Martinez-Rios et al., 2019; Leclercq-Perlat et al., 2006). 
Importantly, the acceptable model performance for L. monocytogenes growth predictions in mould/smear-ripened cheeses required the effect of organic acids and interaction between all environmental factors to be taken into account (Table 3). As an example, L. monocytogenes grew 100-fold during 17 days from day one to 18 in the rind of cheese in challenge test one (Fig. 1). The predicted time for this growth was, respectively, two days and 14-15 days without and with including the effect of lactic acid and using other product characteristics and storage temperature as measured for challenge test one. It has previously been shown that growth prediction for well characterized food products by extensive models, including the effect of relevant growth inhibiting factors, can differ markedly from prediction by simpler models and less characterized foods (Mejlholm et al., 2010; Østergaard et al., 2014). However, most previous studies did not quantify profiles of lactic and other organic acids during fermentation, ripening and storage mould/smearripened cheeses (Back et al., 1993; D’Amico et al., 2008; Ryser and Marth, 1987) and as a consequence the possibility for evaluation and predicting the growth potential of L. monocytogenes was limited.

Classical predictive food microbiology models allow growth or survival of pathogens and spoilage bacteria to be predicted for different constant product characteristics, constant or dynamic storage temperatures and in some cases including the inhibiting effect of the food microbiota on growth of pathogens. Predictions can be used to document food safety, in exposure assessment studies or for safe product reformulations where one set of preserving parameters is changed into another set to reduce for example the concentration of $\mathrm{NaCl} /$ sodium or a specific food preservative (Dalgaard and Mejlholm, 2019; Tenenhaus-Aziza and Ellouze, 2015). In the same way eq. (24) can be used to document food safety and in exposure assessment studies for mould/smear-ripened cheeses but importantly with measured profiles, rather than constant values, for temperature, $\mathrm{pH}$, lactic and acetic acid concentrations and $\mathrm{NaCl} / \mathrm{a}_{\mathrm{w}}$ must be used as model input. However, to 
evaluate potential $L$. monocytogenes growth in mould/smear-ripened cheeses after ripening for example due to contamination by consumers or retailers (Evans and Redmond, 2018; Heiman et al., 2016) and subsequent storage at different temperatures, eq. (24) can be applied as classical predictive food microbiology models because changes in product characteristics will be limited and they might be assumed as constant. Therefore, at this point the major factor to reduce growth of $L$. monocytogenes is temperature. As an example, for a mould-ripened cheese with $\mathrm{pH} 6.3, \mathrm{a}_{\mathrm{w}} 0.973$ and water phase lactic acid concentration of $0.15 \%$, the predicted time for L. monocytogenes to reach the critical cell concentration was $11-22$ days at $4.5^{\circ} \mathrm{C}$ if this product was contaminated with 1 cfu/g (high) or $1 \mathrm{cfu} / 125 \mathrm{~g}$ (low). This contamination may result from consumer or retailer handling of cheeses e.g. by cross-contamination from a different food item. On the other hand, if the cheese was stored at a higher temperature e.g. $8^{\circ} \mathrm{C}$, then the predicted time to reach the critical cell concentration will be 5-10 days for a product contaminated with a high or a low concentration. Storage of refrigerated foods is recommended to be performed by consumers at temperatures below $5^{\circ} \mathrm{C}$. However, several studies have shown that domestic refrigerators work above a mean value of $6^{\circ} \mathrm{C}$ and with some extreme mean values as high as $12^{\circ} \mathrm{C}$ (Dumitraşcu et al. 2020; Roccato et al., 2017). Eq. (24) can be used to educate/advise consumers and retailers on safe storage profiles (timetemperature) of these cheeses after opening of the packaging and cutting of the product.

There is increasing demand for cheeses with reduced salt/sodium content and it is interesting to predict the effect of product reformulation on L. monocytogenes growth. If the rind of mouldripened cheese with product characteristics as in challenge test one was contaminated with $L$. monocytogenes $(1 \mathrm{cfu} / 125 \mathrm{~g})$ on day 15 and stored at $5^{\circ} \mathrm{C}$ then the predicted critical cell concentration (100 cfu/g) would be reached, respectively, 18 days and 15 days after contamination when using the studied $\mathrm{NaCl}$ profile or a profile with $\mathrm{NaCl}$ concentrations reduced by $25 \%$. In agreement with these predictions other studies found $\mathrm{pH}$ and lactic acid concentrations to have more 
impact than $\mathrm{NaCl}$ on L. monocytogenes growth/no-growth/inactivation responses (Shrestha et al., 2011; Wemmenhove et al., 2013).

Several models have been developed to describe the relationship between temperature, lactic acid production in foods and the associated pH value (Leroy and De Vuyst, 2003; Østergaard, 2014). Other models have been developed for growth of moulds and their lactic acid consumption in broth or during ripening of smear soft cheese (Riahi et al., 2007; Aldarf et al., 2006; Adour et al., 2002). However, models are not yet available to predict changes in product characteristics for mould/smear-ripened cheese during fermentation, ripening and storage. The present study therefore used measured product characteristics to predict growth of L. monocytogenes.

The inhibitory effect of high concentrations of lactic acid bacteria on growth of $L$. monocytogenes in cottage cheese, meat and seafood has previously been described empirically by using the Jameson effect model where growth of a pathogen stops when LAB reach their maximum cell concentration (Østergaard et al., 2014; Dalgaard and Mejlholm, 2019). When used in combination with measured dynamic changes in product characteristics the Jameson effect model (Østergaard et al., 2014) markedly underestimated growth of L. monocytogenes in mould-ripened cheese (Results not shown). This was expected as the Jameson effect empirically describe the effect of lactose consumption, lactic acid formation and related decrease of $\mathrm{pH}$ whereas this simple model cannot describe the effect of the subsequent lactic acid consumption and $\mathrm{pH}$ increase in mouldripened cheese. It seems interesting in future studies to model growth and activity of the complex microbiota including $\mathrm{LAB}$ and moulds in mould/smear-ripened cheeses and their microbial interaction with L. monocytogenes. If these models will be able to predict L. monocytogenes growth in mould/smear-ripened cheeses more accurately than the CPM suggested in the present study (Eq. (24)) remain to be evaluated. To improve management of potential L. monocytogenes growth in 
mould/smear-ripened cheeses microbial interaction may be important as yeast and moulds with antilisterial activity may be identified and used as bioprotective cultures (Goerges et al. 2006; Goerges et al., 2011).

The models of Augustin in Coroller et al. (2012) and Østergaard et al. (2014) had a "close to acceptable" performance when predicting growth of L. monocytogenes in mould/smear-ripened cheese (Table 2). However, we selected eq. (24) as it performed better and had a much more realistic $T_{m i n}$-value of $-2.83^{\circ} \mathrm{C}$ (Delignette-Muller et al., 2006; Tienungoon et al., 2000; Ross, 1993) compared to the value of $-5.82^{\circ} \mathrm{C}$ estimated by Coroller et al. (2012). This unusually low $T_{\min }$-value of $-5.82^{\circ} \mathrm{C}$ will result in marked overestimation of $L$. monocytogenes growth rates at low storage temperatures of for example $2-5{ }^{\circ} \mathrm{C}$. For mould/smear-ripened cheeses the model of Østergaard et al. (2014) had the limitation of a $p H_{m i n}$-value for $L$. monocytogenes of 4.87. Consequently, nogrowth will be predicted below that $\mathrm{pH}$-value, irrespective of other product characteristics. This is not optimal as $\mathrm{pH}$ of about 4.5 is common for mould/smear-ripened cheeses and because $L$. monocytogenes can grow at $\mathrm{pH}$-values below 4.87 especially at temperatures of $10-20^{\circ} \mathrm{C}$ (MartinezRios et al., 2019; Nyhan et al., 2018).

In conclusion, a model (Eq. (24)) was identified to acceptably predict growth of $L$. monocytogenes during manufacturing, ripening and storage of mould/smear-ripened cheese. This model can be used to support exposure assessment studies, documentation of food safety and safe reformulations of mould/smear-ripened cheeses. It seems interesting in the future to evaluate if prediction of L. monocytogenes growth in cheeses can be further improved by expanding this model to include terms for the effect of for example butyric acid, propionic acid or other compounds produced during fermentation or ripening of various types of cheeses. 


\section{Acknowledgements}

The Danish Dairy Research Foundation funded the present study as part of the project 'Predictive food microbiology tool for risk assessment and documentation of food safety'.

\section{References}

Adams, M.R., Moss, M.O., McClure, P.J., 2016. Methods for the microbiology examination of foods. In: Food Microbiology. The Royal Society of Chemistry, Croydon, UK, pp. 413-446.

Adour, L., Couriol, C., Amrane, A., Prigent, Y., 2002. Growth of Geotrichum candidum and Penicillium camembertii in liquid media in relation with the consumption of carbon and nitrogen sources and the release of ammonia and carbon dioxide. Enzyme and Microbial Technology 31, 533-542. https://doi.org/10.1016/S0141-0229(02)00149-7

Aldarf, M., Fourcade, F., Amrane, A., Prigent, Y., 2006. Substrate and metabolite diffusion within model medium for soft cheese in relation to growth of Penicillium camembertii. Journal of Industrial Microbiology and Biotechnology 33, 685-692. https://doi.org/10.1007/s10295-006$\underline{0093-4}$

Amato, E., Filipello, V., Gori, M., Lomonaco, S., Losio, M.N., Parisi, A., Huedo, P., Knabel, S.J., Pontello, M., 2017. Identification of a major Listeria monocytogenes outbreak clone linked to soft cheese in Northern Italy - 2009-2011. BMC Infectious Disease 17:342, 1-7. https://doi.org/ 10.1186/s12879-017-2441-6

ANZ, 2018. Standard 1.6.1. Australia New Zealand Food Standards Code - Standard 1.6.1 Microbiological Limits for Food. Available online at: https:// www.legislation.gov.au/Series/F2015L00411/Compilations (Accessed 13 December 2019).

Augustin, J.C., Carlier, V., 2000. Modelling the growth rate of Listeria monocytogenes with a multiplicative type model including interactions between environmental factors. International Journal of Food Microbiology 56, 53-70. https://doi.org/10.1016/s0168-1605(00)00224-5

Augustin, J.C., Zuliani, V., Cornu, M., Guillier, L., 2005. Growth rate and growth probability of Listeria monocytogenes in dairy, meat and seafood products in suboptimal conditions. Journal of Applied Microbiology 99, 1019-1042. https://doi.org/10.1111/j.1365-2672.2005.02710.x

Back, J.P., Langford, S.A., Krollt, R.G., 1993. Growth of Listeria monocytogenes in Camembert and other soft cheeses at refrigeration temperatures. Journal of Dairy Research 60, 421-429. https://doi.org/10.1017/S0022029900027758

CA, 2011. FD-FSNP 0071. Policy on Listeria monocytogenes in Ready-to-Eat Foods. Bureau of microbial hazards, Food Directorate, Canada. Available online at: http://www.food-labelcompliance.com/Sites/5/Downloads/Listeria-monocytogenes-Policy-Health-Canada-040111- 
Apr-2011.pdf (Accessed 13 December 2019).

Coroller, L., 2005. Étude des facteurs non thermiques agissant sur la décroissancen microbienne et moderlisation. $\mathrm{PhD}$ thesis. L'Universite de Bretagne Occidentale, France. http://symprevius.eu/wp-content/uploads/2015/09/PhD_Louis_Coroller.pdf (Accessed 2 January 2020)

Coroller, L., Kan-King-Yu, D., Leguerinel, I., Mafart, P., Membré, J.M., 2012. Modelling of growth, growth/no-growth interface and nonthermal inactivation areas of Listeria in foods. International Journal of Food Microbiology 152, 139-152. https://doi.org/10.1016/j.ijfoodmicro.2011.09.023

D’Amico, D.J., Druart, M.J., Donnelly, C.W., 2008. 60-Day aging requirement does not ensure safety of surface-mold-ripened soft cheeses manufactured from raw or pasteurized milk when Listeria monocytogenes is introduced as a postprocessing contaminant. Journal of Food Protection 71, 1563-1571. https://doi.org/10.4315/0362-028x-71.8.1563

Dalgaard, P., Jørgensen, L. V., 2000. Cooked and brined shrimps packed in a modified atmosphere have a shelf-life of $>7$ months at $0{ }^{\circ} \mathrm{C}$, but spoil in 4-6 days at $25{ }^{\circ} \mathrm{C}$. International Journal of Food Science and Technology 35, 431-442. https://doi.org/10.1046/j.1365-2621.2000.00402.X

Dalgaard, P., 2009. Modelling of microbial growth. Bulletin of the International Dairy Federation 433, 45-60.

Dalgaard, P., Mejlholm, O., 2019. Modelling growth of Listeria and lactic acid bacteria in food environments, in: Foodborne Bacterial Pathogenes, ed A. Bridier (New York, NY: Springer), $1918,247-264$.

Dalzini, E., Cosciani-Cunico, E., Monastero, P., Bernini, V., Neviani, E., Bellio, A., Decastelli, L., Losio, M.N., Daminelli, P., Varisco, G., 2017. Listeria monocytogenes in Gorgonzola cheese: study of the behaviour throughout the process and growth prediction during shelf life. International Journal of Food Microbiology 262, 71-79. https://doi.org/10.1016/j.ijfoodmicro.2017.09.018

Davidson, C.M., Cronin, F., 1973. Medium for the selective enumeration of lactic acid bacteria from foods. Applied Microbiology 26, 439-440.

Delignette-Muller, M.L., Cornu, M., Pouillot, R., Denis, J.B., 2006. Use of Bayesian modelling in risk assessment: aplication to growth of Listeria monocytogenes and food flora in cold-smoked salmon. International Journal of Food Microbiology 106, 195-208.

https://doi.org/10.1016/j.ijfoodmicro.2005.06.021

Dumitraşcu, L., Nicolau, A.I., Neagu, C., Didier, P., Maître, I., Nguyen-The, C., Skuland, S.E., Møretrø, T., Langsrud, S., Truninger, M., Teixeira, P., Ferreira, V., Martens, L., Borda, D., 2020. Time-temperature profiles and Listeria monocytogenes presence in refrigerators from households with vulnerable consumers. Food Control 111, 107078. https://doi.org/10.1016/j.foodcont.2019.107078

EC, 2005. Commission Regulation (EC) No. 2073/2005 of 15 November 2005 on microbiological criteria for foodstuffs. Off. J. Eur. Commun. 338, 1-26. 
Evans, E.W., Redmond, E.C., 2018. Behavioral observation and microbiological analysis of older adult consumers' cross-contamination practices in a model domestic kitchen. Journal of Food Protection 81, 569-581. https://doi.org/10.4315/0362-028X.JFP-17-378FAO/WHO, 2009. Proposed Draft Microbiological Criteria for Listeria monocytogenes in Ready-to-Eat Foods (ALINORM 09/32/13). Codex Alimentarius Commission, $32^{\text {nd }}$ Session, Rome, Italy, 29 June-4 July 2009. http://www.codexalimentarius.net/web/archives.jsp accessed on $10^{\text {th }}$ November 2019.

FDA, 2018. Recalls, market withdrawals \& safety alerts. Food and Drug Administration. https://www.fda.gov/safety/archive-recalls-market-withdrawals-safety-alerts/2018-recallsmarket-withdrawals-safety-alerts (Accessed 13 December 2019).

Giménez, B., Dalgaard, P., 2004. Modelling and predicitng the simultaneous growth of Listeria monocytogenes and spoilage micro-organisms in cold-smoked salmon. Journal of Applied Microbiology 96, 96-109. https://doi.org/10.4315/0362-028X.JFP-17-378

Goerges, S., Aigner, U., Silakowski, B., Scherer, S., 2006. Inhibition of Listeria monocytogenes by food-borne yeasts. Applied and Environmnetal Microbiology 72, 313-318. https://doi.org/10.1128/AEM.72.1.313-318.2006

Goerges, S., Koslowsky, M., Velagic, S., Brost, N., Bockelmann, W., Heller, K.J., Scherer, S., 2011. Anti-literial potential of food-borne yeasts in red smear cheese. International Dairy Journal 21, 83-89. https://doi.org/10.1016/j.idairyj.2010.08.002

Guinee, T.P., Fox, P.F., 2017. Salt in cheese: Physical, chemical and biological aspects in: McSweeney, P.L.H., Fox, P.F., Cotter, P.D., Everett, D.W. (Eds.), Cheese: Chemistry, Physics and Microbiology, Elsevier Ltd, pp. 911-928. https://doi.org/10.1128/AEM.72.1.313-318.2006

Heiman, K.E., Garalde, V.B., Gronostaj, M., Jackson, K.A., Beam, S., Joseph, L., Saupe, A., Ricotta, E., Waechter, H., Wellman, A., Adams-Cameron, M., Ray, G., Fields, A., Chen, Y., Datta, A., Burall, L., Sabol, A., Zucerova, Z., Trees, E., Metz, M., Leblanc, P., Lance, S., Griffin, P.M., Tauxe, R.V., Silk, B.J., 2016. Multistate outbreak of listeriosis caused by imported cheese and evidence of cross-contamination of other cheeses, USA, 2012. Epidemiology \& Infection 144, 2698-2708. https://doi.org/10.1017/S095026881500117X

Kapetanakou, A.E., Gkerekou, M.A., Vitzilaiou, E.S., Skandamis, P.N., 2017. Assessing the capacity of growth, survival, and acid adaptative response of Listeria monocytogenes during storage of various cheeses and subsequent simulated gastic digestion. International Journal of Food Microbiology 246, 50-63. https://doi.org/10.1016/j.ijfoodmicro.2017.01.015

Leclercq-Perlat, M.N., Buono, F., Lambert, D., Latrille, E., Spinnler, H.E., Corrieu, G., 2004. Controlled production of Camembert-type cheeses. Part I: Microbiological and physicochemical evolutions. Journal of Dairy Research 71, 346-354.

https://doi-org.proxy.findit.dtu.dk/10.1017/S0022029904000196

Leclercq-Perlat, M.N, Picque, D., Riahi, H., Corrieu, 2006. Microbiological and biochemical aspects of Camembert-type cheeses depend on atmospheric composition in the ripening chamber. Journal of Dairy Science 89, 3260-3273. https://doi.org/10.3168/jds.S0022$\underline{0302(06) 72601-7}$ 
Leclercq-Perlat, M.N., Hélias, A., Corrieu, G., 2013. Little change takes place in Camembert-type cheese water activities throughout ripening in terms of relative humidity and salt. Journal of Dairy Science 96, 7521-7525. https://doi.org/10.3168/jds.2013-6817

Leclercq-Perlat, M.N., Sicard, M., Perrot, N., Trelea, I.C., Picque, D., Corrieu, G., 2015. Temperature and relative humidity influence the ripening descriptors of Camembert-type cheeses throughout ripening. Journal of Dairy Science 98, 1325-1335. https://doi.org/10.3168/jds.2014-8916

Le Marc, Y., Huchet, V., Bourgeois, C.M., Guyonnet, J.P., Mafart, P., Thuault, D., 2002. Modelling the growth kinetics of Listeria as a function of temperature, $\mathrm{pH}$ and organic acid concentration. International Journal of Food Microbiology 73, 219-237. https://doi.org/10.1016/S0168$\underline{1605(01) 00640-7}$

Leroy, F., De Vuyst, L., 2003. A combined model to predict the functionality of the bacteriocinproducing Lactobacillus sakei Strain CTC 494. Applied and Environmental Microbiology 69, 1093-1099.

Liu, S., Puri, V.M., Demirci, A., 2007. Spacial distribution of population of Listeria monocytogenes during manufacturing and ripening of Camembert cheese. Journal of Food Safety 27, 43-55. https://doi.org/10.13031/2013.16936

Lobacz, A., Kowalik, J., Tarczynska, A., 2013. Modeling the growth of Listeria monocytogenes in mold-ripened cheeses. Journal of Dairy Science 96, 3449-3460.

https://doi.org/10.3168/jds.2012-5964

Martinez-Rios, V., Dalgaard, P., 2018. Prevalence of Listeria monocytogenes in European cheeses: A systematic review and meta-analysis. Food Control 84, 205-214. https://doi.org/10.1016/j.foodcont.2017.07.020

Martinez-Rios, V., Gkogka, E., Dalgaard, P., 2019. New term to quantify the effect of temperature

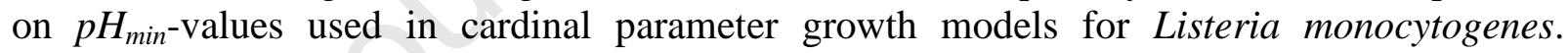
Frontiers in Microbiology 10, 1510. https://doi.org/10.3389/fmicb.2019.01510

McIntyre, L., Wilcott, L., Naus, M., 2015. Listeriosis outbreaks in British Columbia, Canada, caused by soft ripened cheese contaminated from environmental sources. BioMed Research International 131623, 1-12. https://doi.org/10.1155/2015/131623

Mejlholm, O., Dalgaard, P., 2009. Development and validation of an extensive growth and growth boundary model for Listeria monocytogenes in lightly preserved and ready-to-eat shrimp. Journal of Food Protection 72, 2132-2143. https://doi.org/ 10.4315/0362-028x-72.10.2132

Mejlholm, O., Gunvig, A., Borggaard, C., Blom-Hanssen, J., Mellefont, L., Ross, T., Leroi, F., Else, T., Visser, D., Dalgaard, P., 2010. Predicting growth rates and growth boundary of Listeria monocytogenes - An international validation study with focus on processed and readyto-eat meat and seafood. International Journal of Food Microbiology 141, 137-150. https://doi.org/10.1016/j.ijfoodmicro.2010.04.026

Mejlholm, O., Dalgaard, P., 2013. Development and validation of an extensive growth and growth boundary model for psychrotolerant Lactobacillus spp. in seafood and meat products. International Journal of Food Microbiology 167, 244-260. https://doi.org/10.1016/j.ijfoodmicro.2013.09.013 
Membré, J.M., 2017. The importance of predictive microbiology in food safety. EFSA, Parma, June.http://www.parmasummerschool.unipr.it/wp-content/uploads/2018/03/02_JeanneMarieMembre_SS2017.pdf (Accessed on 04 December 2019)

Nyhan, L., Begly, M., Mutel, A., Qu, Y., Johnson, N., Callanan, M., 2018. Predicting the combinatorial effect of water activity, $\mathrm{pH}$, and organic acids on Listeria growth in media and $\begin{array}{lllll}\text { complex food matrices. Food } & \text { Microbiology } & 74,85 .\end{array}$ https://doi.org/10.1016/j.fm.2018.03.002

Oscar, T.P., 2005. Validation of lag time and growth rate models for Salmonella Typhimurium. Journal of Food Science 70, 129-137.

Østergaard, N.B., 2014. Predictive Food Microbiology: new tools for risk assessment and dairy product development. PhD thesis. Technical Univeristy of Denmark.

https://backend.orbit.dtu.dk/ws/portalfiles/portal/103646179/Nina_Bjerre_stergaard_Ph.d._afh andling..PDF(Accessed 22 December 2019)

Østergaard, N.B., Eklöw, A., Dalgaard, P., 2014. Modelling the effect of lactic acid bacteria from starter- and aroma culture on growth of Listeria monocytogenes in cottage cheese. International Journal of Food Microbiology 188, 15-25.

https://doi.org/10.1016/j.ijfoodmicro.2014.07.012

Picque, D., Leclercq-Perlat, M.N., Corrieu, G., 2006. Effects of atmospheric composition on resperitory behavior, weight loss, and appearance of Camembert-type cheeses during chamber ripening. Journal of Dairy Science 89, 3250-3259. https://doi.org/10.3168/jds.S0022$\underline{0302(06) 72600-5}$

Press, W.H., Teukolsky, S.A., Vetterling, W.T., Flannery, B.P., 2007. Integration of ordinary differential equations. Numerical Recepies: The Art of Scientific Computing. Cambridge University Press, New York, 910-915.

RASFF, 2019. Rapid alert system for food and feed. http://www.produktrueckrufe.de/wpfiles/190411_RASFF_Kaese_aus_F.pdf (Accessed 13 December 2019).

Riahi, M.H., Trelea, I.C., Picque, D., Leclercq-Perlat, M.-N., Hélias, A., Corrieu, G., 2007. A model describing Debaryomyces hansenii growth and substrate consumption during a smear soft cheese deacidification and ripening. Journal of Dairy Science 90, 2525-2537. https://doi.org/10.3168/jds.2006-357

Roccato, A., Uyttendaele, M., Membré, J.M., 2017. Analysis of domestic refrigerator temperatures and home storage time distributions for shelf-life studies and food safety risk assessment. Food Research International 96, 171. 181. https://doi.org/10.1016/j.foodres.2017.02.017

Ross, T., 1993. A philosophy for the development of kinetic models in predictive microbiology. $\mathrm{PhD}$ thesis. University of Tasmania. https://eprints.utas.edu.au/22442/1/whole-ross-thesis.pdf (Accessed on 8 January 2020)

Rosshaug, P.S., Detmer, A., Ingmer, H., Larsen, M.H., 2012. Modeling the growth of Listeria monocytogenes in soft blue-white cheese. Applied and Environmental Microbiology 78, 85088514. https://doi.org/10.1128/aem.01865-12 
Rosso, L., Bajard, S., Flandrois, J.P., Lahellec, C., Fournaud, J., Veit, P., 1996. Differential growth of Listeria monocytogenes at 4 and $8^{\circ} \mathrm{C}$ : Consequences for the shelf life of chilled products. Journal of Food Protection 59, 944-949. https://doi.org/10.4315/0362-028X-59.9.944

Ryser, E.T., Marth, E.H., 1987. Fate of Listeria monocytogenes during the manufacture and ripening of Camembert cheese. Journal of Food Protection 50, 372-378. https://doi.org/10.4315/0362-028X-50.5.372

Schvartzman, M.S., Maffre, A., Tenenhaus-Aziza, F., Sanaa, M., Butler, F., Jordan, K., 2011. Modelling the fate of Listeria monocytogenes during manufacture and ripening of smeared cheese made with pasteurised or raw milk. International Journal of Food Microbiology 145, S31-S38. https://doi.org/10.1016/j.ijfoodmicro.2010.11.032

Schvartzman, M.S., Gonzalez-Barron, U., Butler, F., Jordan, K., 2014. Modeling the growth of Listeria monocytogenes on the surface of smear- or mold-ripened cheese. Frontiers in Cellular and Infection Microbiology 4, 90, 1-9. https://doi.org/10.3389/fcimb.2014.00090

Shrestha, S., Grieder, J.A., McMahon, D.J., Nummer, B.A., 2011. Survival of Listeria monocytogenes introduced as a post-aging contaminat during storage of low-salt Cheddar cheese at 4,10 and $21^{\circ}$ C. Journal of Dairy Science 94, 4329-4335.

https://doi.org/10.3168/jds.2011-4219.

Suzuki-Iwashima, A., Matsuura, H., Iwasawa, A., Shiota, M., 2019. Metabolomics analyses of the combined effects of lactic acid bateria and Penicillium camemberti on the generation of volatile compounds in model mold-surface-ripened cheeses. Journal of Bioscience and Bioengineering. https://doi.org/10.1016/j.jbiosc.2019.09.005

Tenenhaus-Aziza, F., Ellouze, M., 2015. Software for predicting microbiology and risk assessment: a description and comparison of tools presented at the ICPMF8 software fair. Food Microbiology 45, 290-299. https://doi.org/10.1016/j.fm.2014.06.026

Tienungoon, S., Ratkowsky, D.A., McMeekin, T.A., Ross, T., 2000. Growth limits of Listeria monocytogenes as a function of temperature, $\mathrm{pH}, \mathrm{NaCl}$, and lactic acid. Applied and Environmnetal Microbiology 74, 75-85. https://doi.org/10.1016/j.fm.2018.03.002

Velugoti, P.R., Bohra, L.K., Juneja, V.K., Huang, L., Wesseling, A.L., Subbiah, J., Thippareddi, H., 2011. Dynamic model for predicting growth of Salmonella spp. in ground sterile pork. Food Microbiology 28, 796-803. https://doi.org/10.1016/j.fm.2010.05.007

Wemmenhove, E., Stampelou, I., van Hooijdonk, A.C.M., Zwietering, M.H., Wells-Bennik, M.H.J., 2013. Fate of Listeria monocytogenes in Gouda microcheese: no growth, and substantial inactivation after extended ripening times. International Dairy Journal 32, 192 198. https://doi.org/10.1016/j.idairyj.2013.05.004

Zuliani, V., Lebert, I., Augustin, J.C., Garry, P., Vendeuvre, J.L., Lebert, A., 2007. Modelling the behaviour of Listeria monocytogenes in ground pork as a function of $\mathrm{pH}$, water activity, nature and concentration of organic acid salts. Journal of Applied Microbiology 103, 536-550. 
Table 1. Overview of the L. monocytogenes growth models evaluated in the present study.

\begin{tabular}{|c|c|c|c|c|c|c|c|c|}
\hline \multirow[b]{2}{*}{ Model } & \multirow[b]{2}{*}{ Developed/validated for: } & \multirow[b]{2}{*}{$\begin{array}{l}\text { Number of } \\
\text { environmental } \\
\text { factors in model }\end{array}$} & \multicolumn{6}{|c|}{ Specific environmental factors in models } \\
\hline & & & Temp. & $\mathrm{NaCl} / \mathrm{a}_{\mathrm{w}}$ & $\mathrm{pH}$ & $\begin{array}{l}\text { Lactic } \\
\text { acid }\end{array}$ & $\begin{array}{l}\text { Acetic } \\
\text { acid }\end{array}$ & $\begin{array}{l}\text { Interactions } \\
\text { between } \\
\text { environmental } \\
\text { factors }\end{array}$ \\
\hline Augustin et al. (2005) & Liquid dairy products/cheeses & 3 & + & + & + & - & - & $t^{\mathrm{a}}$ \\
\hline Schvartzman et al. (2011) & Smear cheese & 4 & + & + & + & + & - & $+{ }^{\mathrm{a}}$ \\
\hline Rosshaug et al. (2012) & White/blue cheese & 4 & + & + & + & + & - & $+{ }^{a}$ \\
\hline Weak acid model ${ }^{\mathrm{b}}$ & Meat, seafood, cheese and vegetables/fruit & 4 & + & + & + & + & - & $+{ }^{a}$ \\
\hline Augustin model ${ }^{\mathrm{b}}$ & Meat, seafood, cheese and vegetables/fruit & 4 & + & + & + & + & - & $+{ }^{\mathrm{a}}$ \\
\hline Dalgaard model ${ }^{\mathrm{b}}$ & Meat, seafood, cheese and vegetables/fruit & 4 & + & + & + & + & - & $+{ }^{a}$ \\
\hline Schvartzman et al. (2014) & Smear/mould cheese & 1 & - & - & + & - & - & - \\
\hline Østergaard et al. (2014) & Cottage cheese & 4 & + & + & + & + & - & $+{ }^{a}$ \\
\hline Martinez-Rios et al. (2019) & Meat, seafood, dairy products and cheeses ${ }^{c}$ & 5 & + & + & + & + & + & $+{ }^{a}$ \\
\hline
\end{tabular}

${ }^{\mathrm{a}}$ Interactions between environmental factors were modelled by using the Le Marc approach (Le Marc et al., 2002).

${ }^{\mathrm{b}}$ Models re-fitted by Coroller et al. (2012) using equations from Zuliani et al. (2007); Augustin et al. (2005) and Mejlholm and Dalgaard (2009).

${ }^{\mathrm{c}}$ Chemically acidified cheese and cream cheese. 
Table 2. Comparison of predicted and observed growth using the acceptable simulation zone (ASZ) method.

$\%$ of observations within the ASZ (\% fail-safe, \% fail-dangerous)

Well characterized cheeses

The present study Rosshaug et al. Schvartzman et

(2012) al. (2011)

Measured
environmental
factors

\section{Eq. (24)}

General

Weak acid in Coroller et al. (2012)

models

Augustin in Coroller et al. (2012)

Dalgaard in Coroller et al. (2012)

Augustin et al. (2005) ${ }^{\mathrm{d}}$

Augustin et al. $(2005)^{\mathrm{e}}$

Østergaard et al. (2014)

Product-

specific

Schvartzman et al. (2014)

models

Temp., pH,

$\mathrm{NaCl} / \mathrm{a}_{\mathrm{w}}$, lactic-

and acetic acids

Temp., $\mathrm{pH}$

lactic acid

Temp., $\mathrm{pH}$

$\mathrm{NaCl} / \mathrm{a}_{\mathrm{w}}$ and

lactic acid

$n=4 \times 3^{b} \quad n=1 \times 2^{b} \quad n=2 \times 2^{b} \quad n=18^{b}$

$\mathrm{N}=\mathbf{6}^{\mathrm{c}}$

$\mathrm{N}=16^{\mathrm{c}}$

$69(23,8)$

$80(20,0)$

$66(25,9)$

$55(36,9)$

$88(12,0)$

$68(26,6)$

$60(30,10)$

$81(13,6)$

$55(45,0)$

$81(19,0)$

$81(19,0)$

$49(49,2)$

$55(45,0)$

$81(19,0)$

$37(6,57)$

$70(21,9)$

$63(38,0)$

$25(0,75)$

$71(0,29)$

$38(25,38)$

$69(25,6)$

$19(0,81)$

$44(55,1)$

$81(19,0)$

$\mathrm{N}=144^{\circ}$

$71(22,7)$

$67(24,9)$

$69(25,6)$

$53(47,0)$

$53(45,2)$

$38(10,52)$

$70(21,9)$

$24(0,76)$

$35(0,65)$

$51(47,2)$

$75(0,25)$

${ }_{-}^{\mathrm{f}}$

$42(2,55)$

\begin{abstract}
Schvartzman et al. (2011)
\end{abstract}
${ }^{a}$ ASZ (\%): Percentage of observed cell concentrations (log cfu/g) within the ASZ (fail-safe, fail-dangerous).

${ }^{\mathrm{b}} \mathrm{n}$ : number of growth curves at dynamic product characteristics and/or storage temperatures.

${ }^{\mathrm{c}} \mathrm{N}$ : number of observation $(\log \mathrm{cfu} / \mathrm{g})$

${ }^{\mathrm{d}}$ Predictions performed with $\mu_{\text {opt }}$ for liquid dairy products $\left(0.742 \mathrm{~h}^{-1}\right)$.

${ }^{\mathrm{e}}$ Predictions performed with $\mu_{o p t}$ for cheese $\left(0.212 \mathrm{~h}^{-1}\right)$.

${ }_{\mathrm{f}}^{\mathrm{f}}$ Data used in model development and therefore excluded when evaluating the performance of the model. 
Table 3. Effect of product characteristics and interaction between environmental factors on the acceptable simulation zone (ASZ) scores when using Eq. (24) to performed predictions.

\begin{tabular}{llcccc}
\multirow{2}{*}{$\begin{array}{l}\text { Challenge tests in } \\
\text { present study }\end{array}$} & $\begin{array}{l}\text { Storage conditions } \\
\text { and growth data }\end{array}$ & \multicolumn{2}{c}{$\begin{array}{c}\text { Including lactic- and acetic acid } \\
\text { concentrations in the water phase }\end{array}$} & $\begin{array}{l}\text { Excluding lactic- and acetic acid } \\
\text { concentrations in the water phase }\end{array}$ \\
\cline { 3 - 6 } & & With interaction & Without interaction & With interaction & Without interaction \\
\hline One & Rind & 55 & 55 & 39 & 39 \\
One & Core & 77 & 47 & 37 & 37 \\
Two & Rind & 72 & 72 & 41 & 41 \\
Two & Core & 73 & 63 & 40 & 40 \\
\hline \hline
\end{tabular}



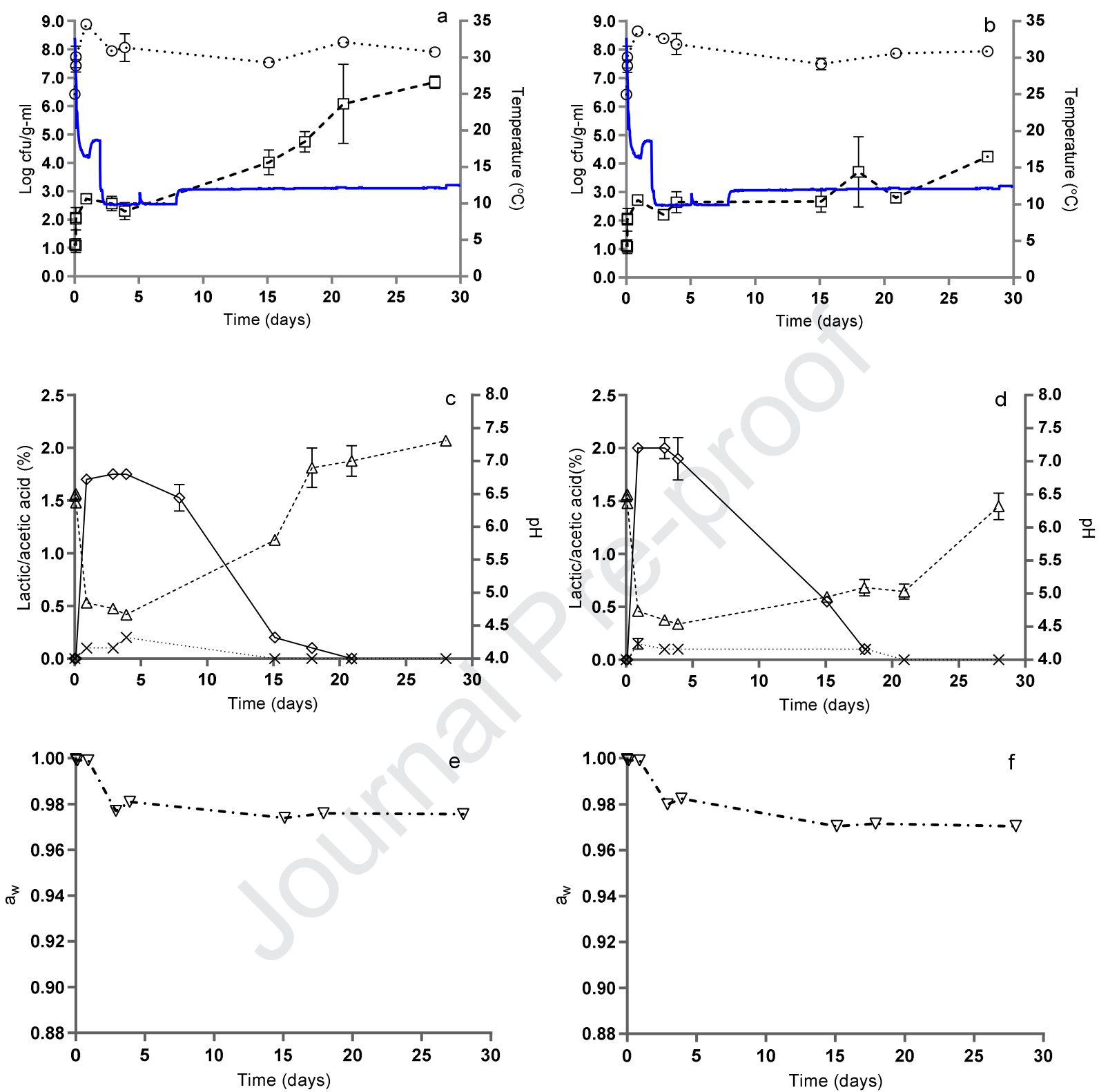

Figure 1. Challenge test one: Growth of L. monocytogenes $(\square)$, lactic acid bacteria $(\circ)$ and changes in $\mathrm{pH}(\triangle)$, lactic acid $(\diamond)$, acetic acid $(\times)\left(\%\right.$ in water phase) as well as $\mathrm{a}_{\mathrm{w}}(\nabla)$ for the rind $(\mathrm{a}, \mathrm{c}, \mathrm{e})$ and for the core $(\mathrm{b}, \mathrm{d}, \mathrm{f})$ of whitemould cheese. The temperature profiles are shown as blue lines (a, b). Symbols represent average values and error bars the standard deviation for three samples. 

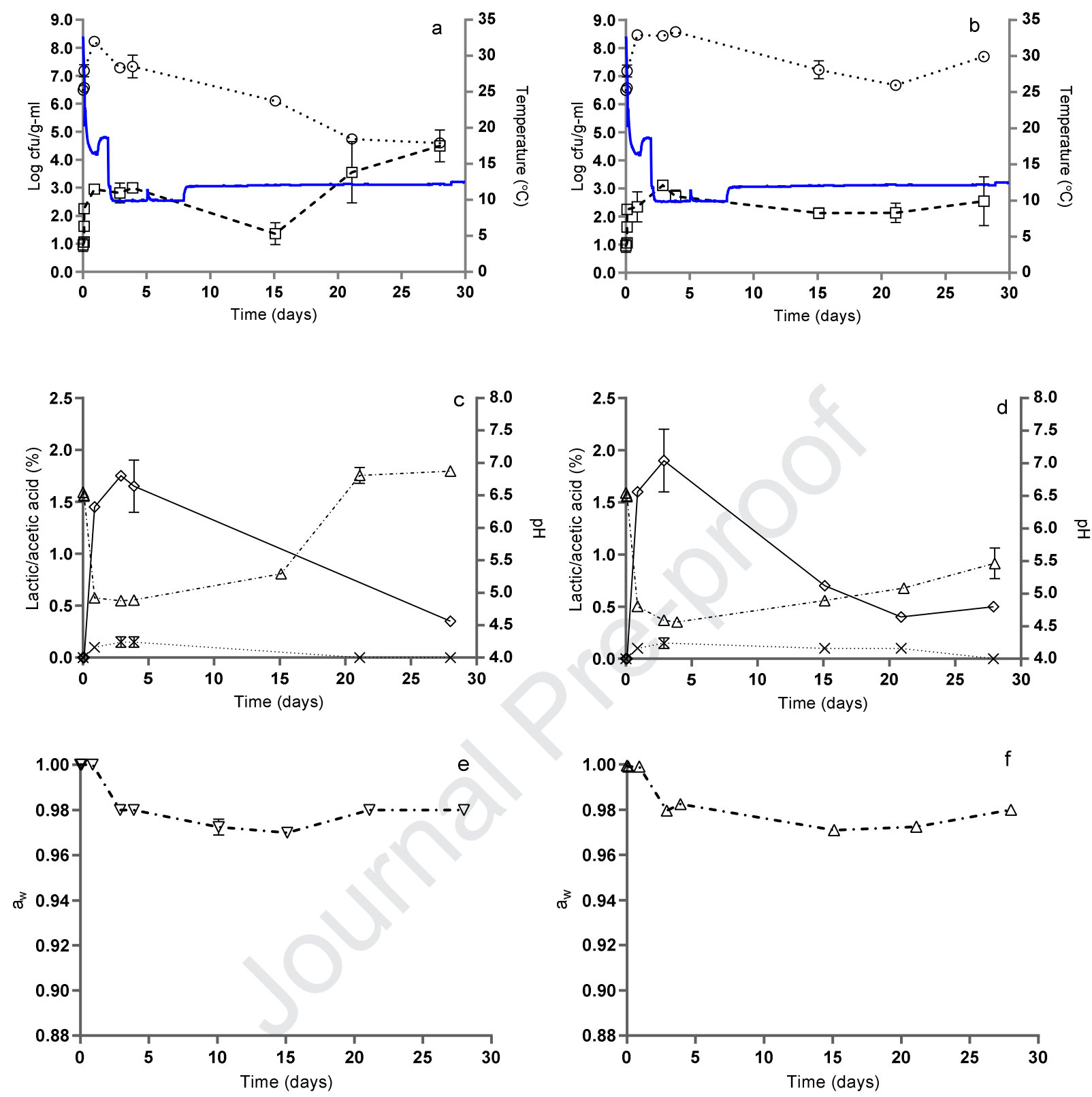

Figure 2. Challenge test two: Growth of L. monocytogenes $(\square)$, lactic acid bacteria $(\circ)$ and changes in pH $(\triangle)$, lactic acid $(\diamond)$, acetic acid $(\times)\left(\%\right.$ in water phase) as well as $a_{w}(\nabla)$ for the rind $(a, c, e)$ and for the core $(b, d, f)$ of whitemould cheese. The temperature profiles are shown as blue lines $(\mathrm{a}, \mathrm{b})$. Symbols represent average values and error bars the standard deviation for three samples. 

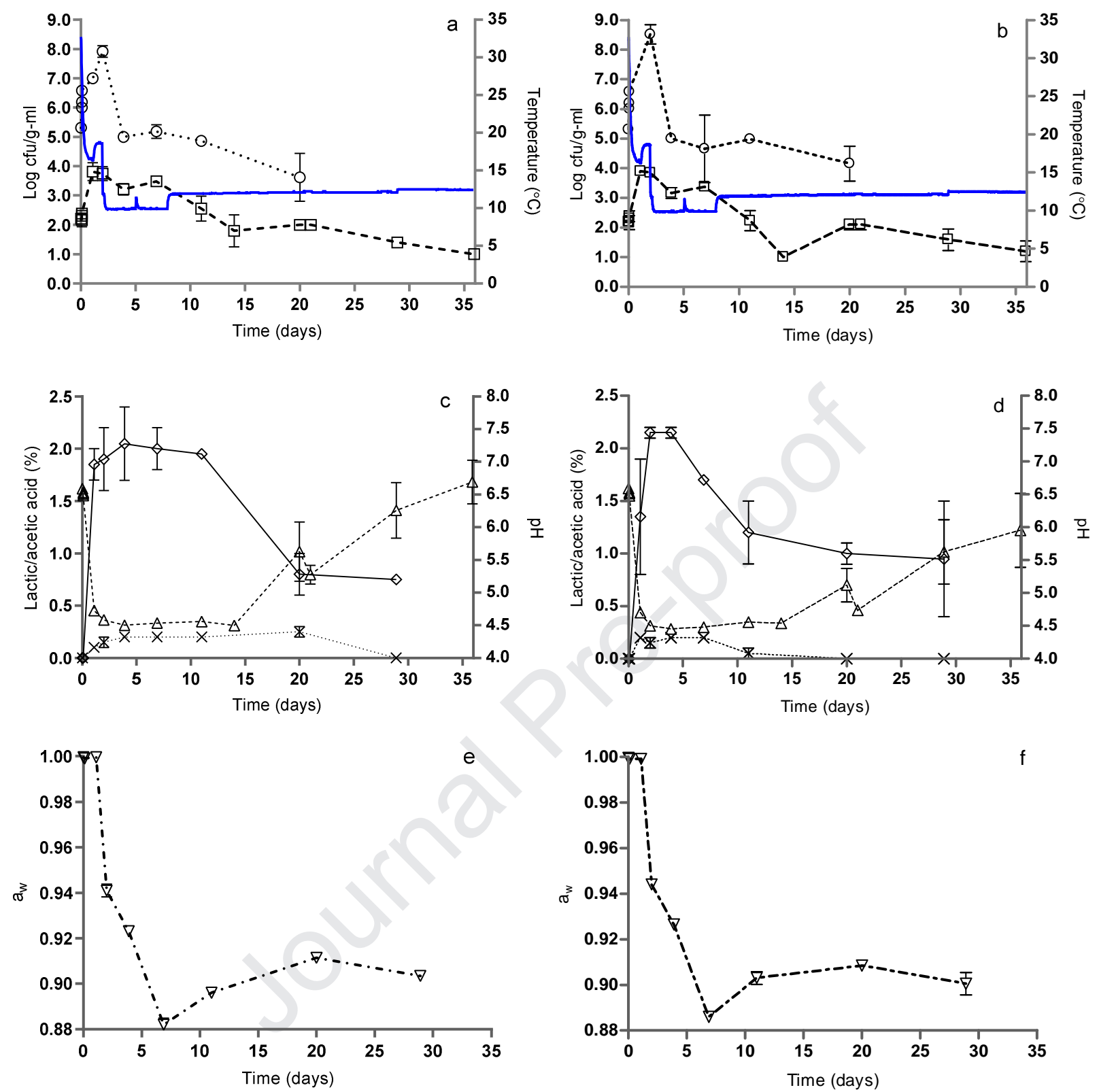

Figure 3. Challenge test three: Growth of L. monocytogenes $(\square)$, lactic acid bacteria $(\bigcirc)$ and changes in pH $(\triangle)$, lactic acid $(\diamond)$, acetic acid $(\times)\left(\%\right.$ in water phase) as well as $a_{w}(\nabla)$ for the rind (a, c, e) and for the core $(b, d, f)$ of whitemould cheese. The temperature profiles are shown as blue lines $(a, b)$. Symbols represent average values and error bars the standard deviation for three samples. 

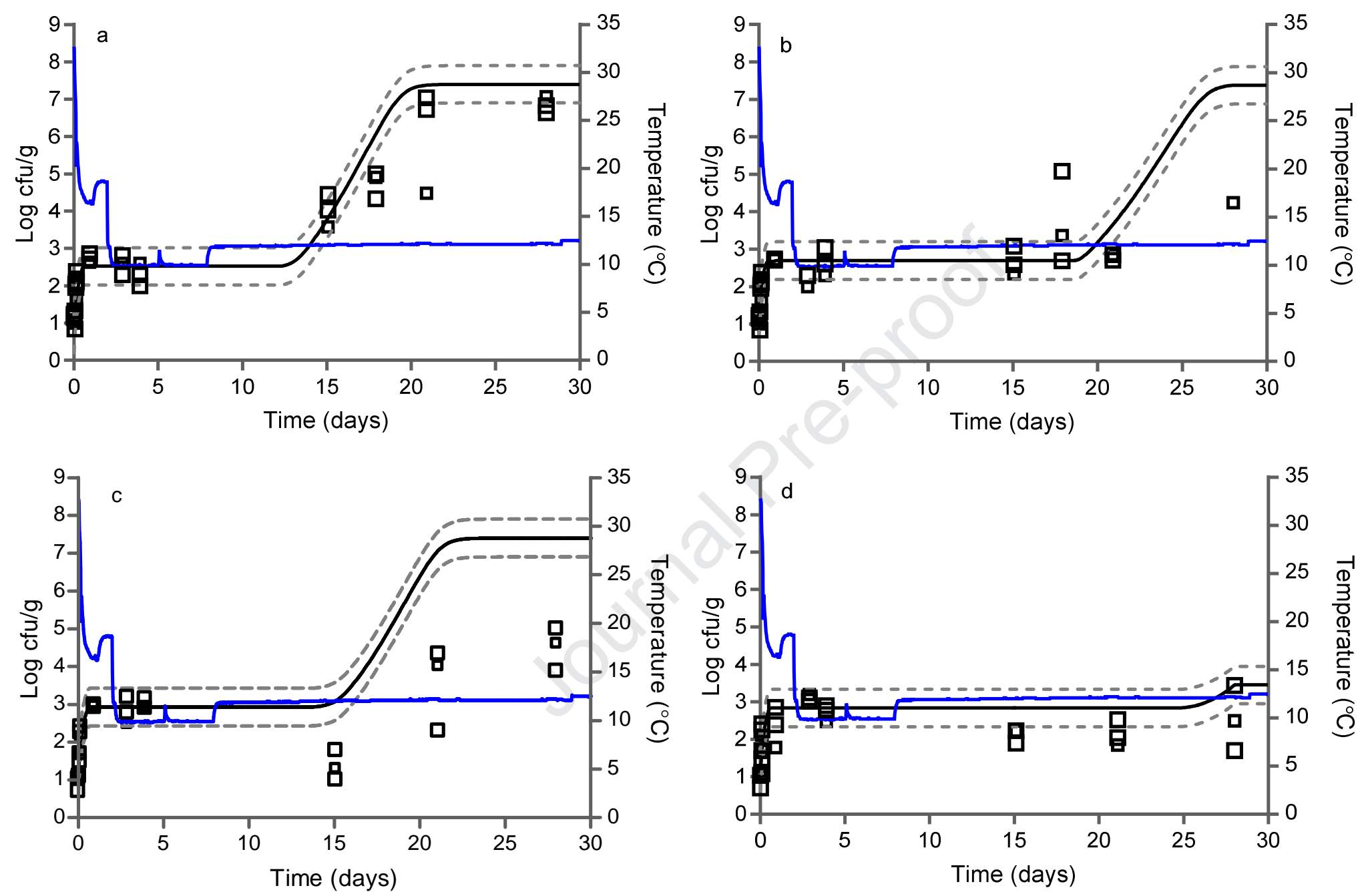

Figure 4. Comparison of observed ( $\square$ ) and predicted (-) growth of L. monocytogenes in the rind (a, c) and in the core (b, d) of challenge test one (a, c) and two (b, d) with white mould-ripened cheese. Solid lines represent the predicted growth by Eq. (24). Graphs include the ASZ ( $\pm 0.5 \mathrm{Log}$ cfu/g, grey dashed lines). The temperature profiles are shown as blue lines. 

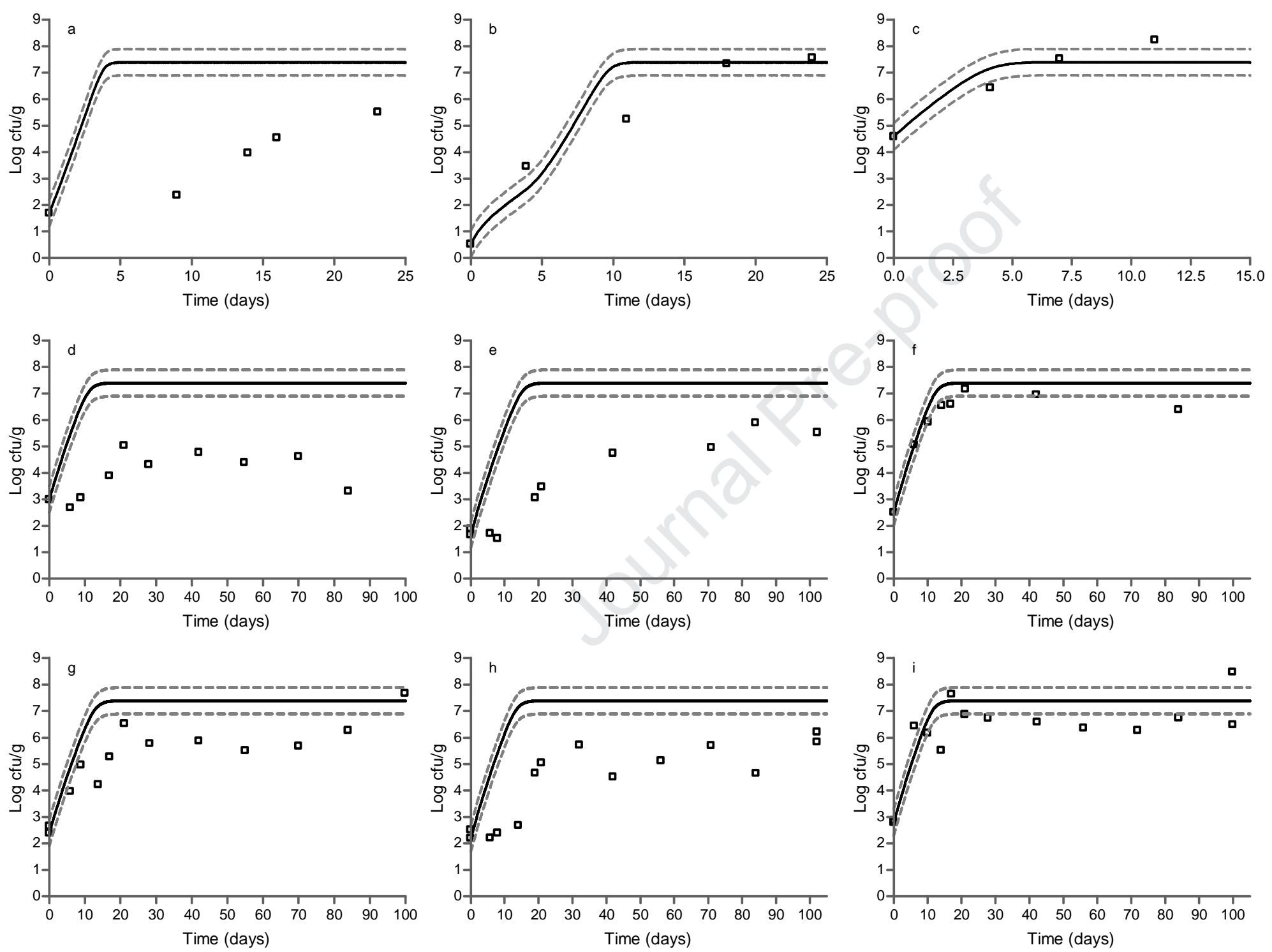


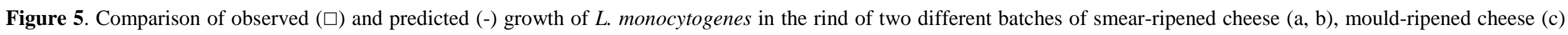

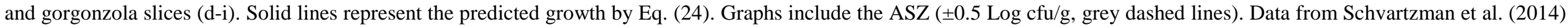

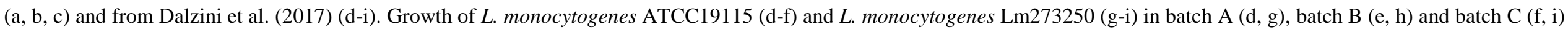
of Gorgonzola cheese. 
Highlights

- Extensive evaluation of models to predict growth of L. monocytogenes in mould/smear-ripened cheeses

- Model including the effect of temperature, $\mathrm{pH}, \mathrm{NaCl} / \mathrm{a}_{\mathrm{w}}$, lactic and acetic acid concentrations

- Predictions can facilitate estimation of safe shelf-life for mould/smear-ripened cheeses 
Conflict of interest

The authors declare that the research was conducted in the absence of any commercial or financial relationships that could be construed as a potential conflict of interest 